\author{
Elena Chygyrynets' and Victoria Vorobyova
}

\title{
A STUDY OF RAPE-CAKE EXTRACT AS ECO-FRIENDLY VAPOR PHASE CORROSION IN HIBITOR
}

\author{
National Technical University of Ukraine \\ 37, Peremogy Ave., 03056 Kiev, Ukraine; corrosionlife@yandex.ru
}

Received: December 06, 2012 / Revised: J anuary 12, 2013 / Accepted: J une 23, 2013

CC Chygyrynets’ E., Vorobyova V., 2014

\begin{abstract}
Rape-cake extract was developed as novel volatile corrosion inhibitors. Its volatiles were analysed by GC-MS. A semi empirical approach was used to rationalize the rape-cake extract inhibitory action. The molecular spatial structure, energy gap and density of extract main compounds have been theoretically investigated using HyperChem7.00.
\end{abstract}

Keywords: rape-cake extract, volatile corrosion inhibitor, DFT calculation.

\section{Introduction}

Atmospheric corrosion of metals in closed spaces, such as in parcels, and during storage and shipment, can be temporarily prevented by the use of certain substances called vapour phase corrosion inhibitors. A vapour phase corrosion inhibitor (VPI) is a compound that has the ability to vaporize and condense on a metallic surface to make it less susceptible to corrosion. The main advantage of VPIs compared with conventional corrosion control methods stems from their gas-phase transport. A VPI reaches the metallic surfaces without contacting the surface directly. The efficacy, convenience, and cost effectiveness of VPIs made their application for rust control almost universal in automotive-manufacturing, steel-making, ship-building, power generation, and defence production [1].

It was found that certain specific VPI formulations can in fact be toxic. For example, dicyclohexyl ammonium nitrite (DICHAN) has been found to be the most effective for inhibiting the atmospheric corrosion of steel, and gained industrial application for several decades [2]. Research confirmed that some N-nitrosoamines, including those generated by DICHAN, were not only carcinogenic, but also hemotoxic as well. Most of the volatile corrosion inhibitors are synthetic chemicals, expensive, and very hazardous to environments. Thus, an alternative of environmental-friendly VPIs is under consideration [3-6].

Nowadays, natural products are viewed as incredibly rich sources of naturally synthesized chemicals for use in most applications. Some of the advantages that natural chemicals have over other types of chemicals include their environmental acceptability and availability. Plant extracts are environment friendly, bio-degradable, non-toxic, easily available and of potentially low cost. Most of the naturally occurring substances are safe and can be extracted by simple procedures. Recent literature is full of researches which test different extracts for corrosion inhibition applications. Numerous naturally occurring products such as Prosopis juliflora [7], Eugenia jambolans [8], Lawsonia opuntia [9], Swertia aungustifolia [10], Ficus religeosa [11], heena [12], Datura stromonium [13] and calotropis plant extracts have been evaluated as potential corrosion inhibitors.

Many of these naturally occurring substances proved their ability to act as corrosion inhibitors for the corrosion of different metals and alloys in different aggressive media. Despite that many plant extract have not been studied as volatile corrosion inhibitors. The rapecake extract (Brassicaceae), which contains many chemicals compounds, may be used as VCIs. Hence, in the present work it has been aimed to investigate the corrosion inhibition efficiency of rape-cake extract as volatile corrosion inhibitors for mild steel.

\section{Experimental}

\subsection{Materials and Apparatus}

The corrosion test and electrochemical measurements were carried out using mild steel strips. The composition of the mild steel is given in \%: $\mathrm{C} 60.15 ; \mathrm{Mn}$ $0.20-0.45 ; \mathrm{P}$ 60.03; S 60.035 and Al, P 0.02. Steel specimens $(50 \times 20 \times 1.5 \mathrm{~mm})$ were used for volatile 
inhibiting sieve test (VIS). The strips were polished by emery paper of $1 / 0,2 / 0$ and $3 / 0$ rinsed with double distilled water, degreased and dried at room temperature.

Rape-cake extract was prepared by macerating in the 2-propanol alcohol for $48 \mathrm{~h}$ and filtered through ordinary filter paper.

\subsection{Gravimetric Measurements}

Volatile inhibiting sieve tests were applied to evaluate the inhibition effect of the VCIs. To obtain reproducible results three samples were used in each test simultaneously. There was a hole in each plate drilled to suspend the sample by a nylon thread. The samples were grinded with $\mathrm{SiC}$ paper to 1000 mesh and were then cleaned in alcohol and rinsed before drying at room temperature. The final geometrical area was $25 \mathrm{~cm}^{2}$. The gravimetric measurement was conducted by suspending the samples in a $250 \mathrm{~cm}^{3}$ conical flask with a tight-fitting rubber cork containing a small dish. The VCIs were dispersed in the dish. The samples with freshly prepared surface were mounted on the flask with and without $1.0 \mathrm{~g}$ inhibitor, respectively. After inhibitor film-forming period of 3 days, $15 \mathrm{~cm}^{3}$ deionized water was added. The test process included cyclic warming and cooling of the samples in a corrosion testing chamber of varying humidity. One cycle included an $8 \mathrm{~h}$ exposure in the thermostat $(323 \pm 1 \mathrm{~K})$, and $16 \mathrm{~h}$ exposure at room temperature. The duration of the test was 21 days.

Corrosion rates $C R \quad\left(\mathrm{~g} \cdot \mathrm{m}^{-2} \cdot \mathrm{h}^{-1}\right)$ and inhibitor effectiveness $I E$ are calculated by means of the following equations:

$$
C R=\frac{W_{0}-W_{1}}{A \cdot T}
$$

where $A$ is the sample area, $\mathrm{m}^{2} ; W_{0}$ is initial weight of the sample, $\mathrm{g} ; W_{1}$ is sample weight after the immersion period, g; $T$ is the immersion period (in h), and $C R_{1}$ and $C R_{2}$ are the corrosion rates without and with inhibitor, respectively.

$$
I E=\frac{C R_{1}-C R_{2}}{C R_{1}} \cdot 100
$$

\subsection{Electrochemical Measurements}

Electrochemical measurements were carried out in stimulated atmospheric corrosion solution in a threeelectrode cell, consisting of a mild steel rod working electrode (WE), a platinum foil counter electrode (CE), and a saturated calomel electrode (SCE) as reference electrode. Polarization electrochemical studies were performed at the facility which includes potentiostat PI50-1 and programmer PR-8. Since it is known that the cathodic process of atmospheric corrosion occurs mainly with oxygen depolarization and great speed, the electrochemical study was conducted under stirring for uniform oxygen flow to the metal surface electrode. We use the mixer MM-5. The WE was mechanically polished on wet silicon carbide ( $\mathrm{SiC}$ ) paper, rinsed with doubledistilled water, degreased with acetone and ethanol, and dried at room temperature. The WE was embedded into an epoxy resin holder exposing $0.385 \mathrm{~cm}^{2}$ surfaces to the solution.

The potential values reported here were versus SCE. The cell was open to the laboratory air and the measurement was conducted without agitation at room temperature $(298 \mathrm{~K})$. All the experiments were carried out in $1 \mathrm{~N} \mathrm{Na}_{2} \mathrm{SO}_{4}$ solution as electrolyte. IE of potentiodynamic polarization measurement was defined as:

$$
I E=\frac{I_{\text {corr }}-I_{\text {corr }(i n g)}}{I_{\text {corr }}} \cdot 100
$$

$\theta$ represents the surface coverage calculated by the following relationship:

$$
\theta=\frac{I_{\text {corr }}-I_{\text {corr }(i n g)}}{I_{\text {corr }}}
$$

where $I_{\text {corr }}$ and $I_{\text {corr(inh) }}$ are the uninhibited and inhibited corrosion current density values.

\subsection{SEM Analyses}

The surface morphology and coating were examined by FEI E-SEM XL 30.

\subsection{GC-M S Analysis}

Component composition of volatile rape-cake extract was investigated by gas chromatography-mass spectrometry on a gas chromatograph "FINIGAN FOCUS" as a detector with a gas chromatograph. For separation of volatiles the $30 \mathrm{~m}, 30.25 \mathrm{~mm}$ I.D., $d_{f}=0.25 \mu \mathrm{m}$ fusedsilica column (HP-5 MS, Hewlett-Packard) was used. The injector and detector temperatures were 523 and $553 \mathrm{~K}$, respectively. Helium was used as carrier gas. The column oven was programmed from $373 \mathrm{~K} \rightarrow 10 \mathrm{~K} / \mathrm{min} \rightarrow 553 \mathrm{~K}$. The temperature of the GC-MS transfer line was $553 \mathrm{~K}$. The mass spectral identification of the free and bound aromatic compounds was carried out by comparing to the NIST-5 (National Institute of Standards and Technology, Gaithersburg, MD). Qualitative analysis (mass spectral data) was verified by comparing the retention indices and mass spectra of identified compounds with those of authentic reference substances.

\subsection{Quantum Chemical Calculations}

Quantum chemical calculations have been performed by the HyperChem 7 [14] package. The 
geometry optimization was obtained by application of the restricted Hartree-Fock method (RHF) using MNDO approach with PM3 parameterization.

According to Koopman's theorem, the frontier orbital energies $E_{\mathrm{HOMO}}$ and $E_{\mathrm{LUMO}}$ are related to the ionization potential $I$, and the electron affinity $A$ of iron and the inhibitor molecule by the following relations: $A=-E_{\mathrm{LUMO}}, I=-E_{\mathrm{HOMO}}$. Absolute electronegativity $\chi$ and absolute hardness $\eta$ of iron and the inhibitor molecule are given by [15]:

$$
\begin{gathered}
\chi=\frac{1}{2}(I+A) \\
\eta=\frac{1}{2}(I-A)
\end{gathered}
$$

The softness $\sigma$ of the inhibitor molecule is simply the inverse of the hardness: $\sigma=1 / \eta$.

If bulk iron metal and the inhibitor molecule are brought together, the flow of electrons will occur from the molecule of lower electronegativity to the iron that has higher electronegativity until the value of the chemical potential becomes equal. The fraction of electrons transferred from the inhibitor molecule to the iron atom will then be given by Eq. (7) [15]:

$$
\Delta N=\frac{\chi_{A}-\chi_{B}}{\eta_{A}+\eta_{B}}
$$

where a theoretical value of $\chi \mathrm{Fe} \approx 7 \mathrm{eV}$ [16] is taken for iron and $\eta_{\mathrm{Fe}}=0$ is taken assuming that $I=A$ for bulk metals [17].

\section{Results and Discussion}

\subsection{Inhibition of M ild Steel Corrosion by the Film of Rape-Cake Extract}

The corrosion rate and inhibition efficiency of mild steel in environment at $100 \% \mathrm{RH}$ in the absence and presence of rape-cake extract are given in Fig. 1. The increase of extract concentration decreases the corrosion rate. The inhibition efficiency achieves $94 \%$. This shows that rape-cake extract can be volatilized and adsorbed on the mild steel surface to protect the steel. To provide high protection the minimal $\mathrm{v} / \mathrm{v}$ ratio inhibitor : enclosed space equal to 1:100 is sufficient.

\subsection{Electrochemical Measurements in Stimulated Atmospheric Corrosion Solution}

Potentiodynamic polarization curves for mild steel in $1 \mathrm{~N} \mathrm{Na}_{2} \mathrm{SO}_{4}$ are shown in Fig. 2. As one can see, the inhibitor causes a decrease in the corrosion rate, i.e. shifts the anodic curves to positive potentials. It is also seen that all these samples shift the corrosion potential significantly to noble direction therefore they are predominantly anodic inhibitors. The inhibition efficiency increases as the extract concentration is increased.

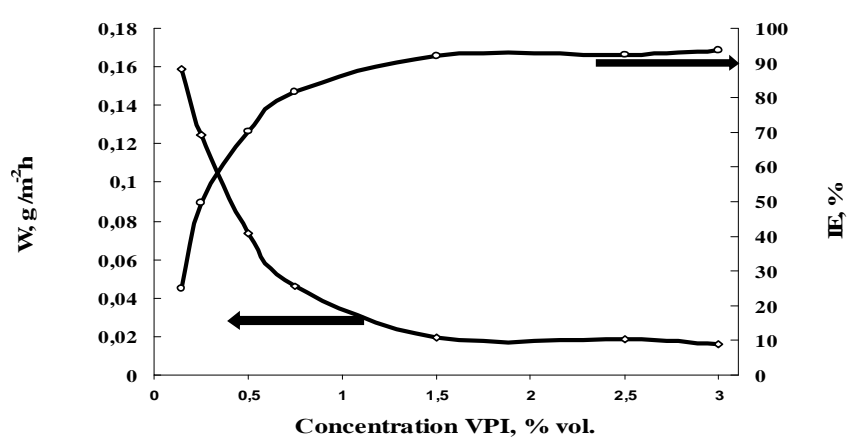

Fig. 1. Variation of corrosion rate $(C R)$ and inhibition efficiency $(I E)$ of corrosion of mild steel for volatile corrosion inhibition test

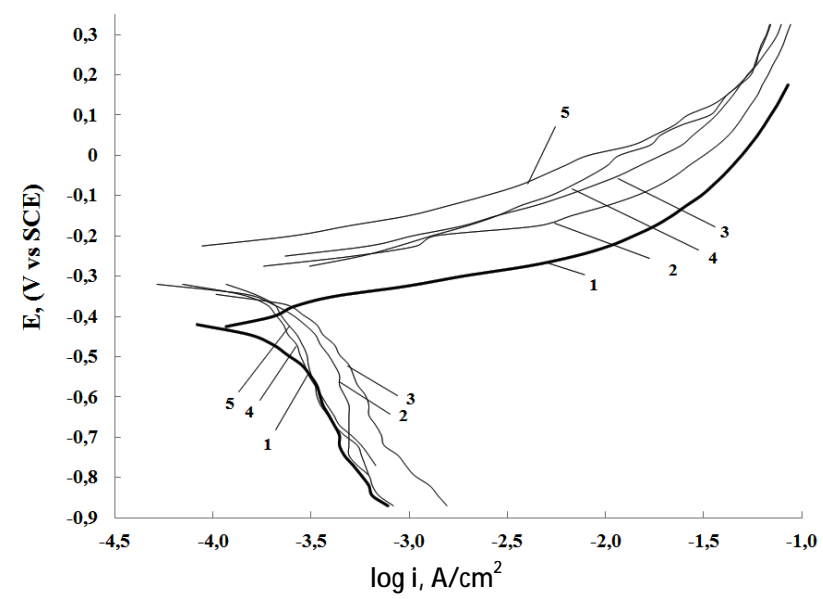

Fig. 2. The polarization behaviour of mild steel in $1 \mathrm{~N} \mathrm{Na}_{2} \mathrm{SO}_{4}$ with (2-5) and without film (1) obtained after the formation for $48 \mathrm{~h}$ in the vapour phase of rape-cake extract at the $\mathrm{v} / \mathrm{v}$ ratio of inhibitor: enclosed space (100 ml): $0.1(2) ; 0.75(3)$; 1.0 (4) and 2.5 (5)

\subsection{Adsorption Isotherm}

It is generally accepted that organic molecules inhibit corrosion by adsorption at the metal surface and the adsorption depends on the molecule's chemical composition. Basic information on the adsorption of inhibitor on metals surface can be provided by adsorption isotherm. Adsorption isotherm plot surface coverage $(\theta)$ obtained from polarization measurements versus log concentration (vol \%) are shown in Fig. 3. Inhibitor concentration was varied in the range of $0.15-5 \mathrm{vol} \%$. 
The straight lines of these plots suggest that the adsorption of volatile compound of the rape-cake extract on mild steel obeys Langmuir adsorption isotherm.

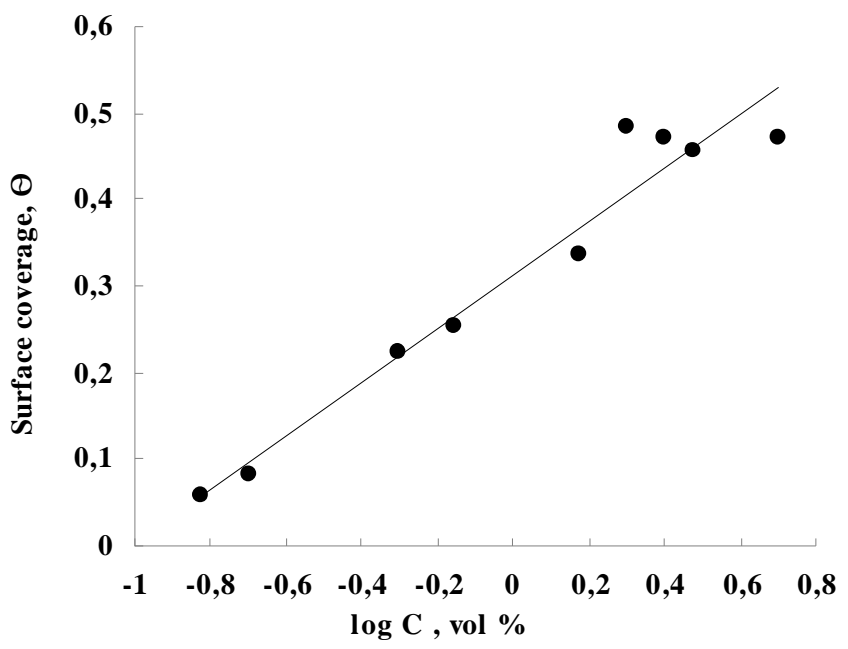

Fig. 3. Langmuir adsorption isotherm plot for mild steel in $1 \mathrm{~N} \mathrm{Na}_{2} \mathrm{SO}_{4}$ after the film-forming of rape-cake extract

\subsection{SEM Analyses}

SEM analyses were conducted in order to characterize the protective layer that formed on the low carbon steel surface. SEM images initial surface and after $48 \mathrm{~h}$ for VCI film-forming are shown in Fig. 4.

The surface morphology of the sample before exposure to volatiles of extract indicates there were a few scratches from the mechanical polishing treatment. This image displays a freshly polished steel surface. The following image (Fig. $4 \mathrm{~b}$ ) is of the steel surface after $48 \mathrm{~h}$ of exposure for the film-forming of the rape-cake extract. It shows a thin and covering surface film.

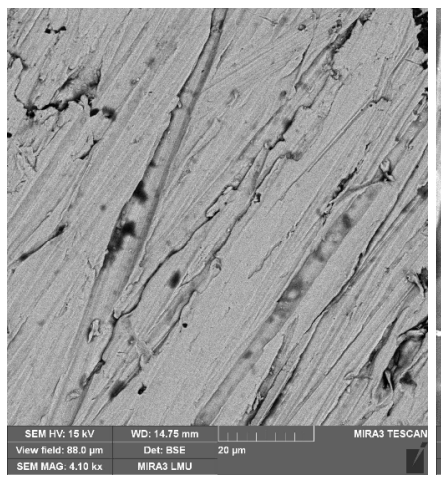

a)

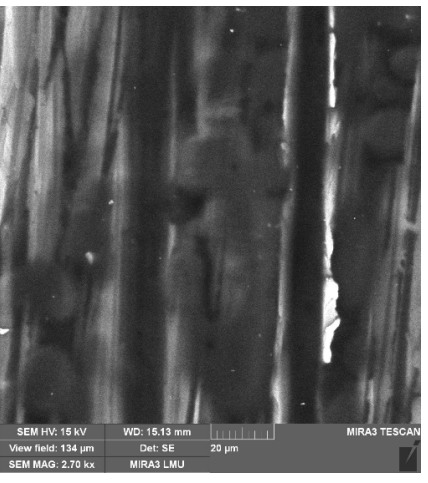

b)
Fig. 4. SEM images of the carbon steel surface: initial surface (a); after $48 \mathrm{~h}$ exposure for VCI film-forming (b)

\subsection{Analysis of Volatiles in Rape-Cake Extract by Gas Chromatography-Mass Spectrometry}

The volatile chemical composition of rape-cake extract is highly complex containing glycosides, nucleosides, ketone, aldehyde, saturated and unsaturated fatty acids, sterols, and alkaloids (Table 1). The most abundant compounds were guanosine (about 10\%), xanthosine $(8 \%)$, dimethoxyacetophenone (12\%), benzaldehyde, 4-hydroxy-3,5-dimethoxy (11.5\%), as well as oleic, linoleic and palmitic acids (about $32 \%$ ).

Table 1

The content of the main components of 2-propanol rape-cake extract

\begin{tabular}{|l|c|}
\hline \multicolumn{1}{|c|}{ Name of the component } & $\begin{array}{c}\text { Weight ratio, } \\
\%\end{array}$ \\
\hline Guanosine & 10.4 \\
\hline Sucrose & 6.2 \\
\hline Xanthosine & 8.3 \\
\hline 3',5'-Dimethoxyacetophenone & 12.3 \\
\hline Benzaldehyde, 4-hydroxy-35-dimethoxy & 11.5 \\
\hline Acetic acid & 5.6 \\
\hline$n$-Cyclohexyl-4-hydroxybytyramide & 1.6 \\
\hline Palmitic acid & 6.1 \\
\hline Linoleic acid & 9.8 \\
\hline Oleic acid & 10.2 \\
\hline Pyrrolidine, 1-(1-oxo-7,10- & 1.5 \\
hexadecadienyl) & 1.2 \\
\hline 2-Pyrrolidine, 1-(9-octadecenly)- & 4.5 \\
\hline Ethanamine, 2,2'-oxybis[N,N-dimethyl]- & 1.4 \\
\hline 7-Dehydrodiosgenin & 1.9 \\
\hline Campesterol & 1.1 \\
\hline$\gamma$ - Sitosterol & 2.9 \\
\hline$b$-Sitosterol & 1.7 \\
\hline Ergosta-5,22-dien-3-ol & 0.9 \\
\hline Stigmast-4-en-3-one & 0.8 \\
\hline Stigmast-3,5-dien-7-one & \\
\hline
\end{tabular}

The inhibition of mild steel corrosion by rape-cake extract is probably attributed to the presence of glycosides, keton and aldehyde since these compounds contain such centres of adsorption as oxygen and nitrogen atoms. All individual chemical compounds are known as inhibitors for several metals [18, 19]. However, it remains unknown what molecules of vapour-phase rape-cake extract are adsorbed on the steel surface and provides inhibition effectiveness.

Studies report that the adsorption process depends on the physicochemical properties of inhibitor molecule, related to the electronic density of donor atoms and on the possible steric effects. It has been established that 
corrosion inhibitors usually promote the formation of a chelate on the metal surface, which include the transfer of electrons from the organic compounds to the metal, forming a donor-acceptor bond during the chemical adsorption process [20-28]. In this adsorption, the metal acts as an electrophile while the inhibitor acts as a nucleophile [29]. Considering the charge transfer characteristics of the adsorption, the wide use of quantum chemical calculations to study this process is justified [30]. Thus, adsorption power of molecules of vapour- phase rape-cake extract was investigated using quantum chemical concepts and the density functional theory (DFT) was applied to study the geometrical and electronic structures of the extract compounds.

The inhibitor molecules structure of rape-cake extract obtained after a geometric optimization procedure using HyperChem 7.0 computer package (RHF calculation, singlet state, PM3 parameterization) and density of the highest occupied molecular orbital are given in Figs. 5 and 6.<smiles>C=C1C2=C(C(=O)C1C)C(C)C(C1CC(C)C(C)(C(C)C)C1)C2C</smiles>

Xanthosine

(1)<smiles>Cc1c(CC(C)C)c(C)c(CC(C)C)c(C(=O)O)c1CC(C)C</smiles>

3',5'-Dimethoxyacetophenone

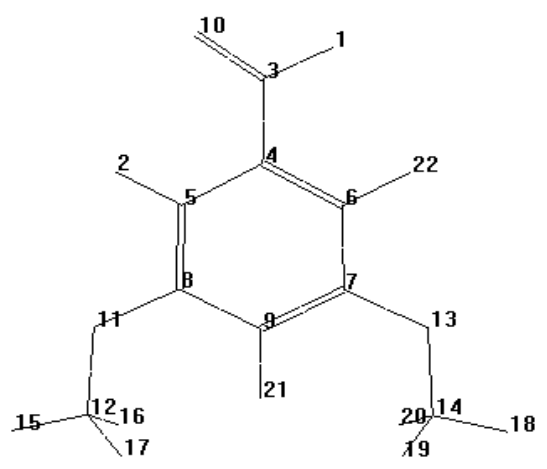

Benzaldehyde, 4-hydroxy-3,5-dimethoxy

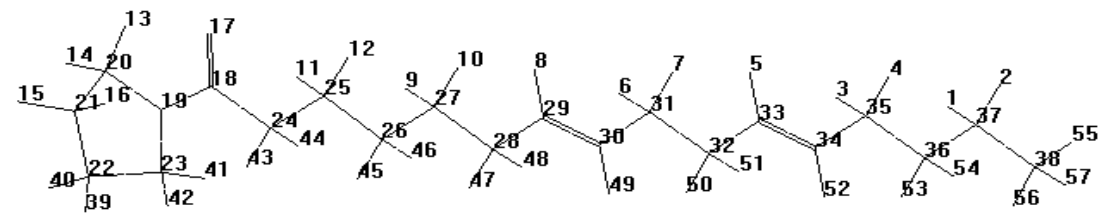

Pyrrolidine, 1-(1-oxo-7,10-hexadecadienyl) (4)

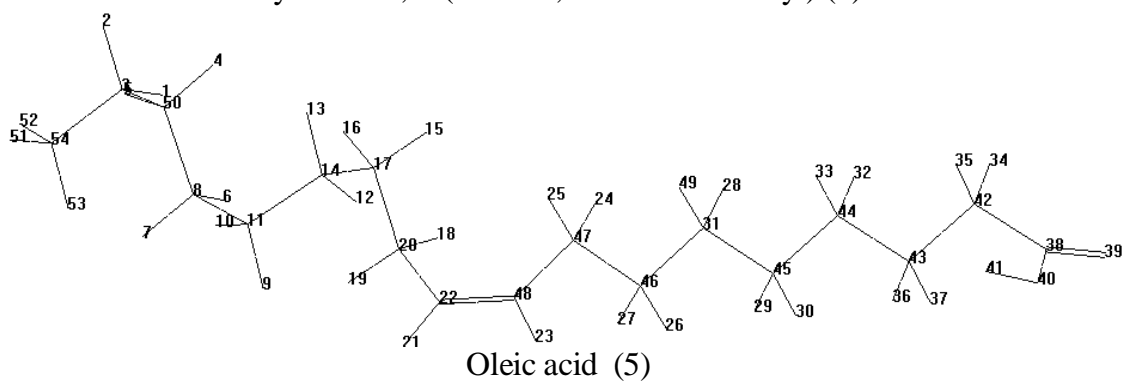

Fig. 5. The inhibitor molecules structure of the rape-cake extract obtained after a geometric optimization procedure using HyperChem 7.0 computer package (RHF calculation, singlet state, PM3 parameterization) 


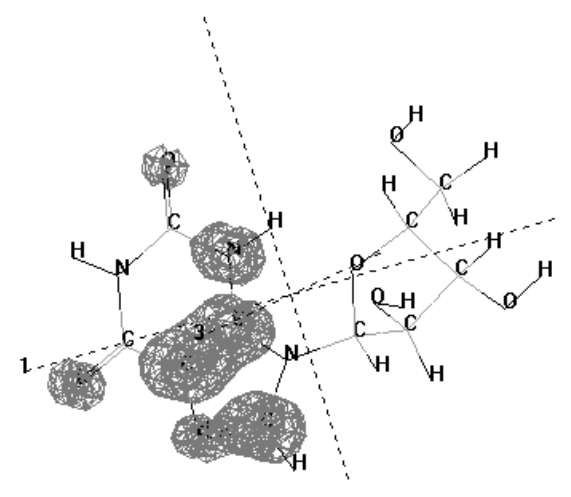

Xanthosine (1)

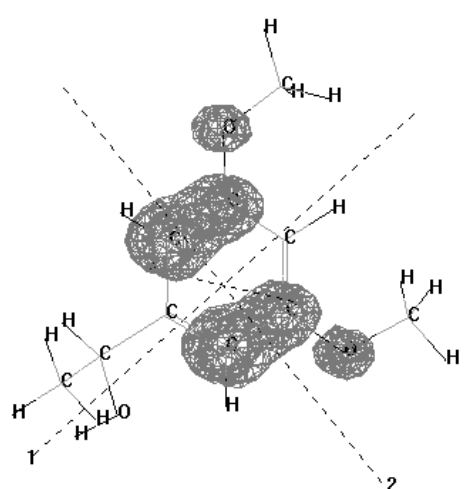

3',5'-Dimethoxyacetophenone (2)

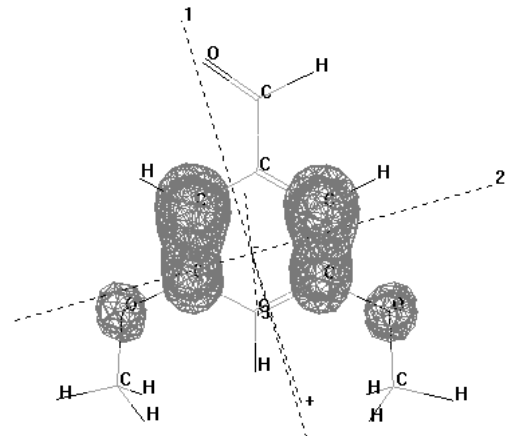

Benzaldehyde, 4-hydroxy-3,5-dimethoxy (3)

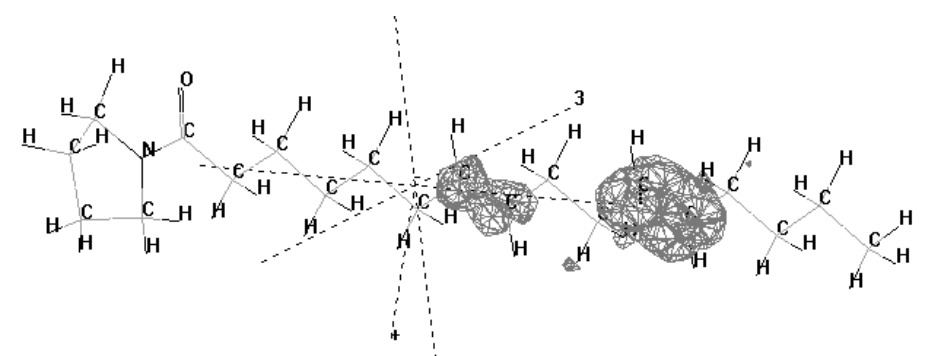

Pyrrolidine, 1-(1-oxo-7,10-hexadecadienyl) (4)
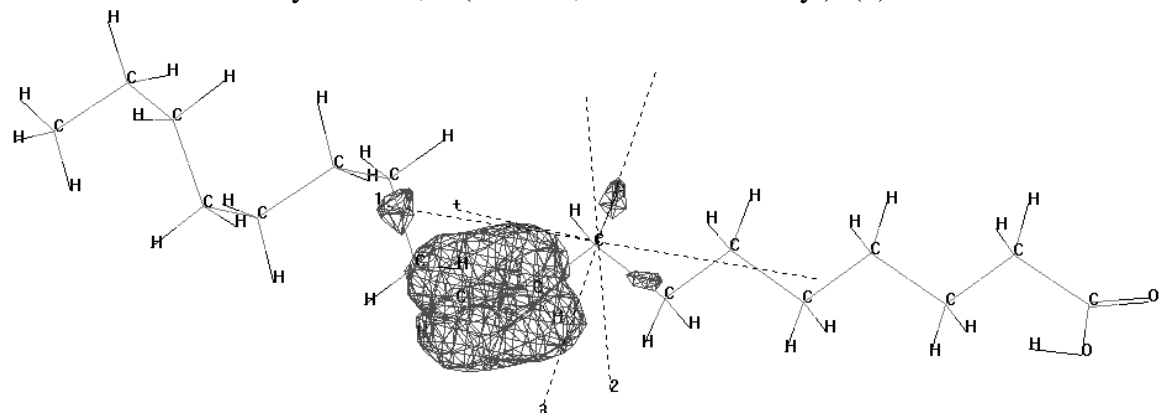

Oleic acid (5)

Fig. 6. Optimized structures of inhibitor molecule 1-5. Density of the highest occupied molecular orbital is shown as a meshed isosurface (orbital density value is equal to 0.005 ) 
Quantum chemical parameters calculated by DFT

\begin{tabular}{|l|c|c|c|c|}
\hline \multicolumn{1}{|c|}{ Molecule } & $\begin{array}{c}E_{\mathrm{HOMO}}, \\
\mathrm{eV}\end{array}$ & $\begin{array}{c}E_{\mathrm{LUMO}}, \\
\mathrm{eV}\end{array}$ & $\begin{array}{c}\Delta E_{\mathrm{L}-\mathrm{H},} \\
\mathrm{eV}\end{array}$ & Ionization potential \\
\hline Xanthosine & -8.973 & 0.217 & 9.19 & 8.973 \\
\hline 3',5'-Dimethoxyacetophenone & -9.081 & 0.211 & 9.29 & 9.081 \\
\hline Benzaldehyde, 4-hydroxy-3,5-dimethoxy & -9.440 & -0.686 & 8.75 & 9.440 \\
\hline Pyrrolidine, 1-(1-oxo-7,10-hexadecadienyl) & -9.759 & 0.983 & 10.74 & 9.759 \\
\hline Oleic acid & -9.883 & 0.907 & 10.79 & 9.883 \\
\hline
\end{tabular}

Table 3

Absolute hardness $(\chi)$, absolute electronegativity $(\eta)$, softness $(\sigma)$ and the number of electrons transferred between the inhibitor molecules and iron $(\Delta N)$ for the investigated compounds

\begin{tabular}{|l|c|c|c|c|}
\hline \multicolumn{1}{|c|}{ Molecule } & $\chi, \mathrm{eV}$ & $\eta, \mathrm{eV}$ & $\sigma, \mathrm{eV}$ & $\Delta N$ \\
\hline Xanthosine & 4.37 & 4.60 & 0.21 & 0.285 \\
\hline 3',5'-Dimethoxyacetophenone & 4.43 & 4.64 & 0.21 & 0.276 \\
\hline Benzaldehyde, 4-hydroxy-3,5-dimethoxy & 5.06 & 4.37 & 0.22 & 0.221 \\
\hline Pyrrolidine, 1-(1-oxo-7,10-hexadecadienyl) & 4.38 & 5.37 & 0.18 & 0.243 \\
\hline Oleic acid & 4.48 & 10.79 & 0.18 & 0.232 \\
\hline
\end{tabular}

It can be seen that the most favourable sites for the interaction with the metal surface were the following atoms:

O10, O11, O13 with charges $-0.294,-0.273,-0.276$ for benzaldehyde, 4-hydroxy-3,5-dimethoxy;

$\mathrm{O} 6, \mathrm{O} 15, \mathrm{O} 16$ with charges $-0.315,-0.278,-0.276$ for 3',5'-dimethoxyacetophenone;

$\mathrm{N} 25, \mathrm{~N} 27, \mathrm{~N} 7, \mathrm{~N} 9, \mathrm{O} 4, \mathrm{O} 10, \mathrm{O} 14, \mathrm{O} 20, \mathrm{O} 22, \mathrm{O} 28$ with charges $-0.394,-0.305,-0.089,-0.195,-0.331,-0.307$, $-0.296,-0.309,-0.307,-0.368$ for xanthosine;

O17, N19 with charges $-0.358,-0.452$ for pyrrolidine, 1-(1-oxo-7, 10-hexadecadienyl);

$\mathrm{O} 39, \mathrm{O} 40$ with charges $-0.300,-0.271$ for oleic acid.

When the HOMO orbital for these molecules is analysed ( Fig. 6) it is found that the highest occupied molecule orbital (HOMO) is in the O11, O13 and C5, C8, C6, C7 for benzaldehyde, 4-hydroxy-3,5-dimethoxy, being the preferred zone for nucleophilic attack.

For xanthosine the HOMO is localized over the nitrogen atoms N27 and N7, and oxygen atom O28 and $\mathrm{O} 24$, being the favourite sites for interaction with the metal surface.

One can see that in $3^{\prime}, 5^{\prime}$-dimethoxyacetophenone molecule (Fig. 6(2)) O6, O15, O16 carry more negative charges while $\mathrm{C} 10, \mathrm{C} 11, \mathrm{C} 12, \mathrm{C} 13$ carry more positive charges. This means that $\mathrm{O} 6, \mathrm{O} 15, \mathrm{O} 16$ are the negative charge centres, which can offer electrons to the $\mathrm{Fe}$ atoms to form coordinate bond and $\mathrm{C} 10, \mathrm{C} 11, \mathrm{C} 12, \mathrm{C} 13$ are the positive charge centres, which can accept electrons from orbital of Fe atoms to form feedback bond.
For oleic acid the HOMO is localized only over $\mathrm{C} 22$ and $\mathrm{C} 48$ the carbon atoms $(-\mathrm{C}=\mathrm{C}-)$, being the favourite sites for interaction with the metal surface. It is found that the highest occupied molecule orbital (HOMO) is in the $\mathrm{C} 29, \mathrm{C} 30, \mathrm{C} 33$ and $\mathrm{C} 34$ for pyrrolidine, 1-(1-oxo7.10-hexadecadienyl), being the preferred zone for interaction with the metal surface.In order to obtain more information about the electronic interaction of the inhibitor molecules with the metal surface the frontier orbital energy such as $E_{\mathrm{HOMO}}, E_{\mathrm{LUMO}}$, energy difference $(\Delta E)$, are used to rationalize the reactivity of the inhibitor molecule and molecule orbital coefficient (Table 2).

The HOMO energy $\left(E_{\text {HOMO }}\right)$ is often associated with the electron donating ability of the molecule, whereas the $E_{\mathrm{LUMO}}$ indicates the ability of the molecule to accept electron. Therefore, high values of the $E_{\text {НОмо }}$ indicate an increased tendency of the inhibitor to donate electron to the vacant $d$-orbital of $\mathrm{Fe}$ in mild steel. According to Wang et al. [31], high values of the $E_{\mathrm{HOMO}}$ facilitate adsorption and enhance inhibition efficiency by influencing the transport process through the adsorbed layer. The highest $E_{\text {номо values are obtained for }}$ xanthosine, 3',5'-dimethoxyacetophenone and benzaldehyde, 4-hydroxy-3,5-dimethoxy.

Large values of the energy gap $\left(\Delta E=E_{\mathrm{LuMO}}-\right.$ $\left.E_{\text {Номо }}\right)$ implies increased electronic stability and low reactivity, while low values render good inhibiting efficiency because the energy to remove an electron from the last occupied orbital will be low [32]. The smaller HOMO-LUMO energy gap implies soft-soft interaction 
will be expected. The inhibitor energy gap increases in the order benzaldehyde, 4-hydroxy-3,5-dimethoxy $<$ xanthosine $<3$ ',5'-dimethoxyacetophenone $<$ pyrrolidine, 1-(1-oxo-7,10-hexadecadienyl) < oleic acid indicating that the latter stable molecule is the strongest inhibitor.

The values of $\chi, \eta, \sigma$ and $\Delta N$ for the molecules are shown in Table 3.

The values of the fraction of electrons transferred $(\Delta N)$ suggest that the inhibitor electron donor strength increases in the same order as the dipole moment $[29,30]$. The value of $\Delta N$ shows inhibition effect resulting from electrons donation. It means if $\Delta N<3.6$ (as obtained in this study) the inhibition efficiency increases with the increase of electron donating ability at the metal surface. In this study the inhibitor molecules of the rape-cake extract are the electron donors and the mild steel surface is the acceptor, thereby binding the inhibitor molecules to the mild steel results in inhibition adsorption layer against corrosion. The inhibition potential of 2-propanol of rapecake extract is attributed to the presence of glycosides, ketone and aldehyde.

\section{Conclusions}

1. A novel volatile corrosion inhibitor (VCI), rape-cake extract, was developed for temporary protection of carbon steel; the maximum inhibition efficiency is about $93 \%$.

2. Rape-cake extract suppressed the anodic reaction of steel electrode and renders the corrosion potential to more noble direction.

3. The volatile chemical composition of rape-cake extract is highly complex containing glycosides, nucleosides, ketone, aldehyde, fatty acids, sterol, and alkaloids.

4. The inhibition action of the extract was attributed to the presence of aldehyde, ketone, and glycosides. The application of the main compounds calculations has been very successful and can be used to understand the inhibition process of corrosion.

\section{References}

[1] Lynch G. and Henders A.: Metal Finish, 2004, 11, 1.

[2] Subramanian A., Natesan M., Muralidharan V. et al.: Corrosion, 2000, 56, 144.

[3] Zhang D. and Gao L.: Mater. Perform., 2003, 42, 40.

[4] Estevao L. and Nascimento R.: Corrosion Sci., 2001, 43, 1133.

[5] Quraishi M. and Jama D.: Corrosion Sci., 2002, 58, 387.
[6] Zhang D., An Z., Pan Q. et al.: Corrosion Sci., 2006, 48, 1437.

[7] Chowdharyand R. and Mathur S.: Electrochem Soc. India, 2005, $\mathbf{5 4}, 1$.

[8] Verma S. and Mehta G.: Trans SAEST, 1997, 32, 89.

[9] El-Etre Y., Abdallah M. and El-Tantway Z.: Corrosion Sci., 2005, 47, 385 .

[10] El-Etre A.: Corrosion Sci., 2003, 45, 2485.

[11] Zakvi S. and Mehta G.: Trans SAEST, 1988, 23, 407.

[12] Jain T., Chowdhary R. and Mathur S.: Mat. Corrosion, 2006, 57, 422 .

[13] Chetouani A. and Hammouti B.: Bull. Electrochemical, 2003,19, 23.

[14] Dewart M., Zoebish E., Healy E. and Stewart J.: J. Am.Chem. Soc., 1985, 107, 3902.

[15] Pearson R.: Inorg. Chem., 1988, 27, 734.

[16] Klopman G.: J. Am. Chem. Soc., 1968, 90, 223.

[17] Sastri V. and Perumareddi J.: Corrosion, 1996, 53, 671.

[18] Slater J.: Introduction to Chemical Physics. Dover, New York 1970.

[19] Rozenfel'd I. and Persiantseva V.: Ingibitory Atmosfernoi Korrozii. Nauka, Moskwa 1985.

[20] Evans U.: The Corrosion and Oxidation of Metals. Edward Arnold, London 1976.

[21] Xia S., Qiu M., Yu L. et al.: Corrosion Sci., 2008, 50, 2021.

[21] El Ashry H., El Nemr A., Esawy S. and Ragab S.: Electrochimica Acta, 2006, 51, 3957.

[23] Karelson M. and Lobanov S.: Chem. Rev., 1996, 96, 1027.

[24] Eddy N. and Odoemelam S.: Pigment and Resin Techn., 2009, 38, 111.

[25] Eddy N., Odoemelam S. and Odiongenyi A.: Appl. Electrochemical, 2009, 39, 849.

[26] Odiongenyi A., Odoemelam S. and Eddy N.: Portugaliae Electrochemical Acta, 2009, 27, 128.

[27] Ebenso E., Arslan T., Kandemirli F. et al.: Int. J. Quantum Chem., 2010, 110, 1003.

[28] Fang J. and Li J.: Theochem., 2002, 593, 179.

[29] Eddy N., Odoemelam A. and Ekwumemgbo P.: Scient. Research and Essay, 2009, 4, 33.

[30] Lukovits E., Kalman F. and Zucchi F.: Corrosion (NACE), 2001, 57, 3.

[31] Ju H., Kai Z.-P. and Li Y.: Corrosion Sci., 2008, 50, 865.

[32] Wang H., Wang X. and Wang L.: J. Mol. Mod, 2007, 13, 147.

\section{ДОСЛІДЖЕННЯ ЕКСТРАКТУ ШРОТУ РІПАКУ ЯК ЕКОЛОГІЧНО БЕЗПЕЧНОГО ЛЕТКОГО ІНГІБІТОРУ КОРОЗІї}

Анотація. Екстракт шроту ріпаку досліджений як новий леткий інгібітор атмосферної корозії сталі. Методом газової хромато-мас-спектрометрії отримано компонентний склад його летких фракиій. 3 використанням програми НурегChет7.00 були проведені квантово-хімічні розрахунки основних компонентів екстракту.

Ключові слова: екстракт шроту ріпаку, леткий інгібітор корозії, квантово-хімічні розрахунки. 